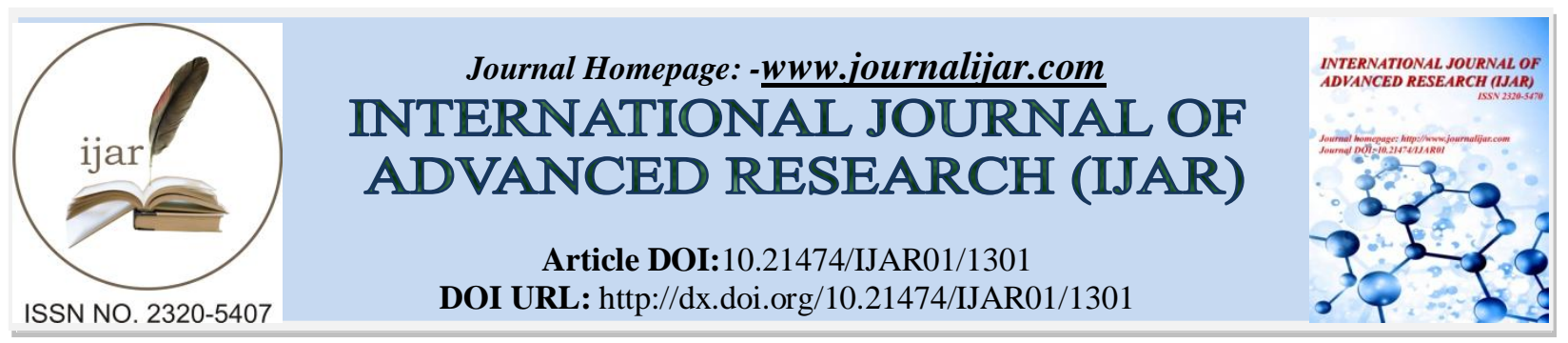

RESEARCH ARTICLE

\title{
CRITICAL DISCOURSE ANALYSIS OF Z.A BHUTTO'SSPEECH AT SECURITY COUNCIL (15 DECEMBER, 1971) IN PERSPECTIVE OF TRANSITIVITY AND MODALITY.
}

Bushra Munawar.

Kean University, NJ. United States.

\section{Manuscript Info}

Manuscript History

Received: 19 June 2016

Final Accepted: 19 July 2016

Published: August 2016

Key words:-

Critical Discourse Analysis (CDA),

Transitivity, Modality, Systemic

Functional Linguistics (SFL), Language

and Politics, Political Discourse,

Textuality.

\section{Abstract}

The Critical Discourse Analysis (CDA) is often applied to analyze political discourse including the public speech, in which the speaker wins hearts of the audience. This research paper presents the Critical Discourse Analysis (CDA) of Z.A Bhutto's (a former Prime minister of Pakistan) speech through Systemic Functional Linguistics (SFL) which serves a theoretical framework for the present research work. The aim of the present study is to explore and reveals the way the language serves as a vehicle to exercise the notions of ideology and power. A detailed analysis of this speech enables us to understand their basic purpose of the used language in the speech. Additionally, we can have a good understanding of the political purpose of the speech in our daily lives. Because political speeches are not merely speeches rather these aimed to influence the minds of the listeners (Audience), and to fulfill several other hidden motives of the politicians in the field of politics.

Copy Right, IJAR, 2016. All rights reserved.

\section{Introduction:-}

The aim of this investigation is to discover how the political speeches made by politicians influence the minds of public and grab their attention to achieve their own personal aims. For this purpose, the present study presents a discourse analysis of a political speech of Z.A Bhutto, a former prime minister and an active politician in the history of Pakistan. To serve this end, the text of one political speech has been explored through two basic approaches of discourse analysis;

a. Systemic Functional Linguistics (SFL)

b. Critical Discourse Analysis (CDA)

The present study is interpretative through and through. The interpretation and explanation is done in many steps. The interpretation begins with the very act of identifying and selecting text of a speech from Bhutto's political scenario. However, before describing the 'procedure' of selection and interpretation of data, it is important to define a text first.

The text of Bhutto's speech is chosen from one of the most important perspectives of his political scenario as his speech on 15 December, 1971 in Security Council. It plays an important role in popularity of Zulfikar Ali Bhutto. 


\section{Literature Review:-}

The researchers have presented a literature review related to Critical Discourse Analysis (CDA) and Systemic Functional Linguistics (SFL) theory in a chronological order in order to present the employed theoretical framework in a very simple way for better understanding of the presented work. And in the end the researchers have discussed the political discourse so that a better linkage could be built because the present research is on the political speech of Z.A. Bhutto.

\section{An Overview of Discourse Analysis:-}

Discourse analysis is not a simple field of study. It takes into account the language both spoken and written, in the real communication. Discourse analysis in its everyday practice deals with texts as heterogeneous as advertisement, biological research articles, police interviews, newspaper editorials, and life stories.

Halliday \& Hassan (in Sinar 2007: 7) say that text is the unit of language usages. It's not the grammatical unit like clause and sentence and it is not defined by following its length". In discourse analysis, the word text generally, refers to the record of situation process (discoursed according to Gregory (in Sinar 2008: 7) involved without any limitation on language systems.

According to Sinar (2007: 8), text is just like a live thing on the language level and text is also as a semantic unit that is the source of meaning maker. It can realize the meaning which is controlled by the discourse of meaning. As a matter of fact, morpheme, word, phrase, clause realize a wording which is controlled by the grammar and lexicon. Phoneme realizes the sound (phonology) and realizes grapheme/a letter (graphology). The analysis of text can be done in the level below text that is investigating some aspects such as: grapheme/phoneme, morpheme, word, phrase, clause that is vertically to the bottom and analyzing the linguistic variables. Next, we can analyze the text vertically to the top by investigating the context variables of linguistic that is the context of situation, culture, and ideology. The variables that still exist above the text interact or influence each other along with the text. All the variables of context are found in the text and globally all the potentials are analyzed depending on the needs or aim which is intended by the researcher and which determines the social life. The discourse is closely related to the contexts of situation, culture, and ideology.

Critical Discourse Analysis (CDA):-

Critical Discourse Analysis (CDA) is obviously not a homogenous model, nor a school or a paradigm, but at most a shared perspective on doing linguistics, semiotic or discourse analysis. (Van Dijk 1993b: 131)

Critical Discourse Analysis (CDA) is a type of discourse analytical research that primarily studies the way social power abuse, dominance, and inequality are enacted, reproduced, and resisted by text and talk in the social and political context. With such unorthodox research, critical discourse analysts take explicit position and thus want to understand, expose, and ultimately resist social inequality (Van Dijk, T. A. 2006).

Critical Discourse Analysis (CDA) views language as social practice and places a lot of importance on the context of language use. A vital attribute of the Critical DiscourseAnalysis (CDA) is its perceived interest in the direct relationship between language and power (Wodak, 2001, p.2). The language used by a speaker can convey some powerful meaning to the hearer depending on the type of language used and how the speaker communicates with his audience. It has often been associated with politics and struggle. Wodak. (2001) provide a more detailed description of Critical DiscourseAnalysis (CDA). They advise that it "is fundamentally concerned with analysing opaque as well as transparent structural relationships of dominance, discrimination, power and control as manifested in language" (Wodak, 2001, p.2). The three dimensional model of text, discursive practice and social practice is a crucial concept in doing a Critical DiscourseAnalysis (CDA).

Critical research on discourse needs to satisfy a number of requirements in order to effectively realize its aims:

- As is often the case for more marginal research traditions, CDA research has to be "better" than other research in order to be accepted.

- It focuses primarily on social problems and political issues rather than on currentparadigms and fashions. 
- Empirically adequate critical analysis of social problems is usually multidisciplinary. Rather than merely describe discourse structures, it tries to explain them in terms ofproperties of social interaction and especially social structure.

- More specifically, CDA focuses on the ways discourse structures enact, confirm, legitimate, reproduce or challenge relations of power and dominance in society.

\section{Systemic Functional Linguistic in CDA:-}

M.A.K. Halliday has sought to create an approach to linguistics that treats language as foundational for the building of human experience. His insights and publications form an approach called Systemic-Functional Linguistics (SFL)/ Grammar. This SFL is usually considered the main foundation of Critical Discourse Analysis as well as other theories in pragmatics (Wilcock.G 2001). The approach views language as a resource that is fundamentally shaped by the uses that people make of it; it therefore aims to explain the forms of language in terms of the meanings that they express, and to develop a grammar which is designed to make it possible to say sensible and useful things about any text, spoken or written' (Halliday 1994).

A key concept in Halliday's approach is the "context of situation" which obtains "through a systematic relationship between the social environment on the one hand, and the functional organization of language on the other" (Halliday, 1985:11). The following are the main principles adopted in SFL when analyzing linguistic phenomena:

1. Language is viewed as complete text, not merely a collection of words or linguistic rules.

2. Linguistic forms are created to deliver meaning.

3. Language is functional.

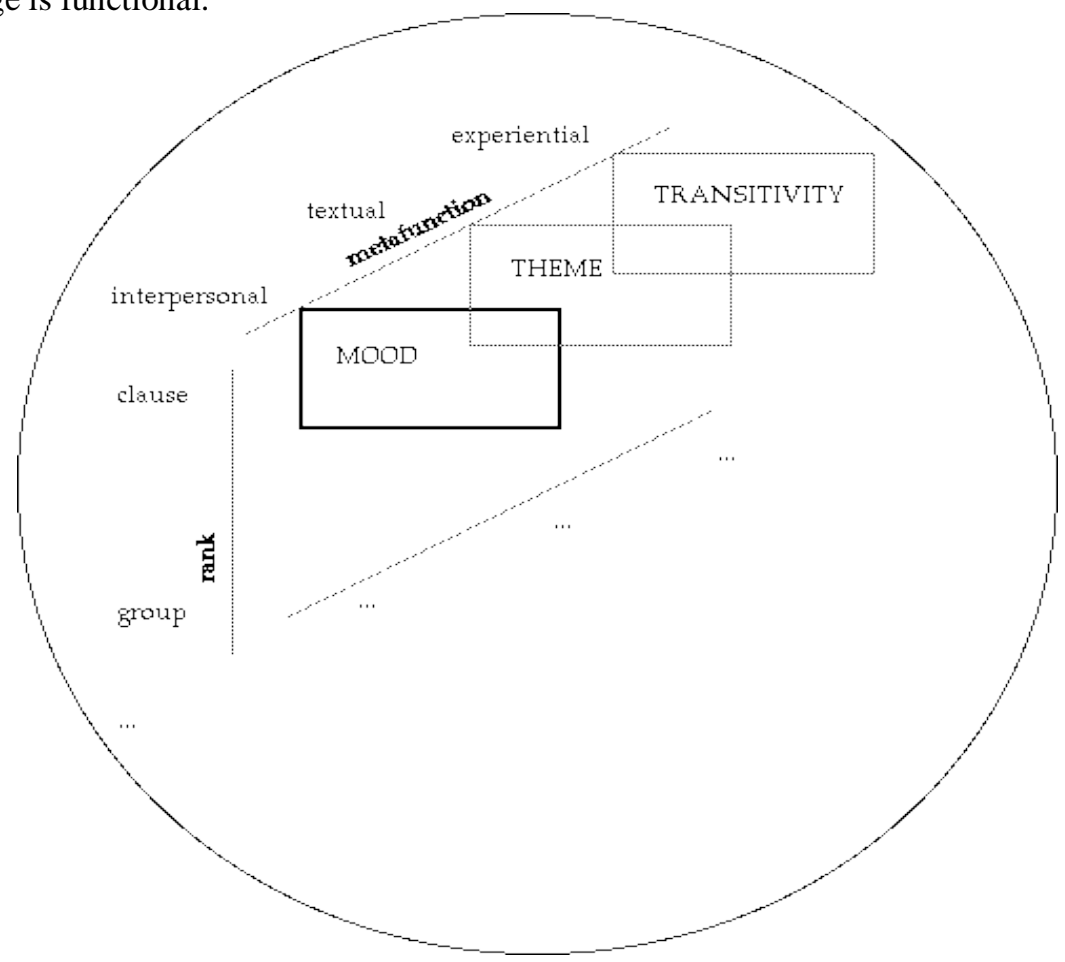

Fig.2.1:-The view of the grammar so far, relative to expansion by metafunction and rank.

Figure 2.1 locates the MOOD 'corner' of the grammar in relation to the other most general systems, according to the two dimensions of metafunctionand rank. Metafunction refers to the different modes of meaning construed by the grammar; rank refers to the different 'sizes' of the grammatical units (layers of constituency). I will discuss each of these concepts in turn, followed by a short account of the third dimension (Matthiessen, C., \& Halliday, M. A. K. 1997).

\section{Metafunctions of Language:-}

Systemic Functional Linguistics (SFL) describes that language is functional. In general, metafunctions of language give the message which has good formulation. Meta-functions of language consist of three major functional 
components, they are: The Ideational Function, The Interpersonal Function, and The Textual Function (Sinar, 2007: 55-57).

Halliday (2006) argues that the system networks that can be identified fall into three main groupings, with interaction between systems in any one group, but little or no interaction between the systems across groupings (Matthiessen 2006 provides corpus-based evidence to support this claim). The three groupings of systems make up what Halliday calls three metafunctions, each of which realize different broad types of meaning (Chapman, Siobhan and Routledge, Christopher 2009) which are as given below;

- The ideational/experiential function

- The interpersonal function

- The textual function

\section{Ideational Function:-}

It is through this function that the speaker or writer embodies in language his experience of the phenomena of the real world; and this includes his experience of the internal world of his own consciousness: his reactions, cognitions, and perceptions, and also his linguistic acts of speaking and understanding (Halliday, 1971: 332). In other words, this function is to convey new information, to communicate a content that is unknown to the hearer. It reflects the events and experience in both objective and subjective worlds.

Material Processes are those in which something is done. These processes are expressed by an action verb (e.g. eat, go, give), an Actor (logical subject) and the Goal of the action (logical direct object, usually a noun or a pronoun) (Hu Zhuanglin, 1988).

For Example;

They weremaking supper.

Actor Process Goal

\section{The car crashed into a tree.}

\section{Actor Process Circumstance}

Mental Processes express such mental phenomena as "perception" (see, look), "reaction" (like, please) and "cognition" (know, believe, convince). A mental process is associated with two participants, Senser and Phenomenon (Hu Zhuanglin, 1988).

For Example;

Shesaw them leaving the house.

Sensor Phenomenon

Relational Processes is the process of being; whose central meaning central meaning is something is attribute, and identity (Sinar 2003: 63). And it can be classified into two types and those are as Attributive and Identifying. The former expresses what attributes a certain object has, or what type it belongs to, for example, The temperature is high. The latter expresses the identical properties of two entities. For example, Lily is a girl; the girl is Lily (Hu Zhuanglin, 1988).

1) Attributive: Associated participants: Carrier \& Attribute

2) Identifying: Associated participants: Token \& Value (Identified \& Identifier)

A 'Carrier' is construed as being ascribed or attributed to an 'Attribute': the relation can be interpreted as one of class-membership - the Carrier is construed as a member of the class described by the Attribute.

Table 2.2:- Relational Process(SFL presentation on University of OSLO site).

\begin{tabular}{|l|l|l|l|}
\hline Carrier & Process & Attribute & Circumstance \\
\hline His clothes & are & very expensive. & \\
\hline You & are & a fool. & \\
\hline The barracks & has become & an art gallery & now. \\
\hline Some granite & has & large crystals. & \\
\hline
\end{tabular}


In identifying clauses a general relationship of symbolization is construed between two participants, the 'Identified' and the 'Identifier'. The relationship can also be characterized as one between 'Token' and 'Value'.

For Example;

This sentence is an example of an identifying clause.

\begin{tabular}{llr} 
Identified & \multicolumn{1}{c}{ Identifier } \\
Token & Process & Value
\end{tabular}

Verbal processes are those of exchanging information. Commonly used verbs are say, tell, talk, praise, boast, describe, etc. In these processes the main participants are Sayer, Receiver and Verbiage (Associated participants: Sayer and Verbiage (+ Receiver).

For Example;

She told methe story of her life.

Sayer Verbiage Receiver

Behavioral Processes refer to physiological and psychological behavior such as breathing, coughing, smiling, laughing, crying, staring, and dreaming, etc. Generally there is only one participant-Behaver, which is often a human. This kind of processes is much like the mental process. Behavioral process may sometimes be hardly distinguished from a material process that has only one participant. This depends on whether the activity concerned is physiological or psychological. When Behavioral process has two participants (Associated participant: Behaver (Range), we may take it as material process (Hu Zhuanglin, 1988).

For Example;

- They hummed a little tune.

- His father beat the disobedient boy.

Existential Processes represent that something exists or happens. In every existential process, there is an Existent.

For Example;

- There is a girl in the garden.

- Does ghost exist on earth?

\section{Interpersonal Function:-}

In the second place, language serves as interpersonal function. Theinterpersonalmetafunction is concerned with the interaction between speaker and addressee(s) - the grammatical resources for enacting social roles in general, and speech roles in particular, in dialogic interaction; i.e. for establishing, changing, and maintaining interpersonal relations. One of its major grammatical systems is MOOD, the grammaticalization of speech function that we have already met (Matthiessen, C., \& Halliday, M. A. K. 1997).

According to Yates, interpersonal function is a propositional content; modality through (in English) modal auxiliaries, e.g., (Yates, 1996:42).

$\circ$ modals of obligation (must, need, should)

$\circ$ modals of ability and possibility (can, could)

- modals of epistemic possibility (may, might)

$\circ$ modals of volition and prediction (will, shall)

○ hypothetical modals: (would, should)

Modality refers to the intermediate ranges between the extreme positive and the extreme negative. It is one of the most important systems in social communication. On the one hand, it can objectively express the speaker's judgment toward the topic. On the other hand, it can show the social role relationship, scale of formality and power relationship (Junling Wang, 2010).

The role of modality serves as a tool to signal various levels of politeness in most of the world languages. Politeness is a 'pragmatic' mechanism (Weydt, 1983) but can also be termed as a 'lay concept' and a 'sociolinguistic concept'. Brown and Levinson (1987) presented their theory in terms of two major categories:

- Positive Politeness

- Negative Politeness 
Positive Politeness refers to the want of every member that his wants be desirable to at least some others. It usually tries to minimize the distance between people by expressing friendliness and solid interest in the hearer's need to be respected (minimize the FTA).

Negative Politeness refers to the want of every 'competent adult member' that his action be unimpeded by others. The main focus for using this strategy is to assume that you may not be imposing on the hearer, and intruding on their space. Therefore, these automatically assume that there might be some social distance or awkwardness in the situation.

\section{Textual Function:-}

The third role of language is called textual function. The textual metafunction is concerned with the creation of text - with the presentation of ideational and interpersonal meanings as information that can be shared by speaker and listener in text unfolding in context (Matthiessen, C., \& Halliday, M. A. K. 1997).

The textual function fulfils the requirement that language should be operationally relevant, having texture in a real context of situation that distinguishes a living passage from a mere entry in a grammar book or a dictionary. It provides the remaining strands of meaning potential to be woven into the fabric of linguistic structure. Information can be clearly expressed in a discourse. It can also be implicated between the lines. Therefore, all discourses are unities of explicit and implicit message (Halliday, 1971).

Systemic Functional Grammar (SFG) is the most fully-developed alternative to what was, for much of the twentieth century, the main linguistic paradigm, which aimed to split the problem of describing language into separate areas such as syntax, semantics, sociolinguistics, and so on. SFG rejects that kind of 'divide-and conquer' solution, on the grounds that language is a resource for social communication and can only be properly understood if that whole picture is taken into account at all stages of investigation. Its orientation to language in use means that it has been widely adopted in discourse analysis and corpus linguistics and in a range of other areas, most notably education, natural language generation and language acquisition studies (Chapman,S and Routledge,C; 2009, p.231).

After discussing different approaches to discourse analysis, Critical Discourse Analysis (CDA) and Systemic Functional Linguistics (SFL), it is necessary to discuss political discourse also in order to find out how such kind of discourse is different from other discourses. And because the present research work is based on political discourse.

\section{Political Discourse Analysis:-}

Discourse is a broad term with various definitions which "integrates a whole palette of meanings" (Titscher 2000, p.42), covering a large area from linguistics, through sociology, philosophy and other disciplines. According to Fairclough (1989) the term refers to "the whole process of interaction of which a text is just a part" (Fairclough, 1989, p.24). As pervasive ways of experiencing the world, discourses refer to expressing oneself using words. Discourses can be used for asserting power and knowledge, and for resistance and critique. The speaker expresses his/her ideological content in texts as does the linguistic form of the text. That is, selection or choice of a linguistic form may not be a live process for the individual speaker, but the discourse will be a reproduction of that previously learned discourse. Texts are selected and organized syntactic forms whose "content-structure" reflect the ideological organization of a particular area of social life (Dellinger, 1995).

\section{Language and Politics:-}

How does language of political speeches influence the minds of listeners while remaining in the political discourse? When we think of politics, we think of it mainly in terms of the struggle for power in order to secure specific ideas and interests and put them into practice. This process of manifesting a political will and transforming it into concrete social action is realized first of all between political parties. In this process, language plays an important role. In fact, any political action is prepared, accompanied, controlled and influenced by language.

One problem in the complex of language and politics, however, is how to define what political discourse is. Particularly in the twentieth century, as a result of the massive expansion of print and electronic media, more and more people are exposed to discourse that may be characterized as political in nature. In addition, more and more people are involved in their daily life in political action, by, for example, being asked to cast their votes in an election, or by watching the news on TV or reading a newspaper, or simply by talking with friends about the 
consequences which recent decisions of the government might have for each individual. The opportunities for each person to be more or less actively involved in political discourse have increased enormously.

\section{Political Speeches:-}

The characterization of a text as political can be based on functional and thematic criteria. Political texts are a part of or the result of politics, they are historically and culturally determined (see the contributions in Bochmann, 1986). They fulfill different functions due to different political activities. Their topics are primarily related to politics, i.e. political activities, political ideas, political relations, etc. Another characteristic feature is that, in the majority of cases, they are meant for a wider public.

A linguistic analysis of political discourse in general and of political speeches in particular, can be most successful when it relates the details of linguistic behavior to political behavior. This can be done from two perspectives: we can start from the linguistic micro-level and ask which strategic functions specific structures (e.g. word choice, a specific syntactic structure) serve to fulfill. Either we can start from the macro-level, i.e. the communicative situation and the function of a text and ask which linguistic structures have been chosen to fulfill this function. For both perspectives, the political situations and processes can be linked to discourse types and levels of discourse organization by way of an intermediate level, that of strategic functions. The most important such strategic functions are coercion, resistance, opposition and protest, dissimulation, and legitimization and de-legitimization (see Chilton \&Schäffner, 1997).

\section{Review of Related Literature:-}

Different researchers have worked on political speeches from linguistics point of view in Europe but no one worked on the political speeches of Z.A Bhutto especially in this context. So it is the first attempt made by researchers to analyze one of important speech of Z.A Bhutto according to the theoretical frame work of Critical Discourse Analysis (CDA) and Systemic Functional Linguistics (SFL).

Research indicates that the Critical DiscourseAnalysis (CDA) has a direct relationship with the language of domination and force and focuses on spoken and written words as the basis for the analysis. Leading experts in linguistics have identified three concepts that are inherent in the Critical Discourse Analysis (CDA) namely; the concept of power, the conceptof history and the concept of ideology (Wodak, 2001, p.3). It can be used to analyse speeches made by politicians and other civic society leaders who have a lot of power. Here the researcher has presented the exemplary work on the Critical Discourse Analysis of Martin Luther King "I Have a Dream".

\section{Rationale of the Study:-}

As a matter of fact, many researchers have critically analyzed different speeches of politicians across the world but nobody has conducted research on the speeches of Z.A Bhutto in perspective of critical discourse analysis (CDA) and systemic functional linguistics (SFL) in Pakistan so far. Zulfikar Ali Bhutto remains a controversial figure in Pakistan. While he was hailed for being a nationalist, Bhutto was roundly criticized for opportunism and intimidating his political opponents. He gave Pakistan its first constitution, oversaw Pakistan's nuclear program, held peace talks with neighbor India and was more of an Internationalist with a secular image.

Owing to his controversial image, the researchers chose his famous speech in Security Council that might be taken as a potential subject for the analysis and to find the answers to the following research questions.

\section{Research Questions:-}

The following research-questions motivated the researcher to analyze the political speeches of Z.A Bhutto (that serves as the data for the present study).

1) Is Systemic Functional Linguistics (SFL) an influential tool to exploit the text of political speeches for the sake of Critical Discourse Analysis (CDA)?

2) To what extend do experiential functions occur in Z.A Bhutto's speech?

3) What are the dominant types of experiential process found in Z.A Bhutto's speech?

\section{Research Methodology:-}

A major part of this study follows Qualitative method as far as the choice of the research instrument (text of the speeches) and the technique employed for the analysis (SFL and CDA). The usage of the linguistics items to 
exercise the discourse strategies used by the speaker (Z.A Bhutto) has been displayed statistically through tables and through constitutes a quantitative part of the present study.

\section{Theoretical Framework:-}

In this present study, one selected political speech of Z.A Bhutto is analyzed in perspective of Critical Discourse Analysis (CDA) and Systemic Functional Linguistics (SFL) especially in perspective of Transitivity and Modality.

\section{Mode of Research:-}

The mode of research for this research work is qualitative dominantly and as well as quantitative because much of the statistical analysis will be there in analysis of speech. Critical analysis of the Bhutto's political speech and functional approach of the language especially in context of transitivity and modality has been the point of research work in the present study. To ensure the triangulation of the research techniques, models and theories are used for analysis of text.

\section{Analysis / Results:-}

Statistical analysis of sample speeches based on word (tokens), sentences, sentence mean length and word mean length.

Table 4.1:- Total no. of words, paragraphs and characters.

\begin{tabular}{|l|l|}
\hline \multirow{2}{*}{ Statistical Item } & Statistic \\
\cline { 2 - 2 } & My Country Beckons Me \\
\hline Words (Tokens) & 4,594 \\
\hline Sentences & 313 \\
\hline Paragraphs & 25 \\
\hline Characters & 21,177 \\
\hline Sentence Mean Length & 14.678 \\
\hline Word Mean Length & 4.610 \\
\hline
\end{tabular}

In above table 4.1, the researcher has given a complete statistical analysis of the selected speech of Z.A Bhutto. There are 4,594 words in consisting of 313 sentences. And these 313 sentences are in 25 paragraphs where sentence mean length is 14.678 and word mean length is 4.610 .

4.2 Six types of process with their core meanings and participants involving in each process

Table 4.2:-Overview of Process Types (Peng Pingping, 2007)

\begin{tabular}{|l|l|l|}
\hline Process Types & Core Meaning & Participants \\
\hline Material & "doing, happening" & Actor, Goal \\
\hline Mental & "sensing" & Sensor, phenomenon \\
\hline Relational & "being" & \\
\hline Verbal & "saying" & Sayer, Receiver, Verbiage \\
\hline Behavioral & "behaving" & Behaver \\
\hline Existential & "existing" & Existent \\
\hline
\end{tabular}

The researchers have given the above table 4.2, in order to have a complete overview of the whole process of metafunctions of language that comes under Systemic Functional Linguistics (SFL). Each type of the process is defined with its core meanings and the participants involved in it. This overview is presented by Peng Pingping (2007) in order to describe the meta-functions of the language. It is necessary to present a complete overview of the metafunctions before starting analysis of the selected speeches accordingly.

4.3 Identification of the Material Process present in both sample speeches 
Table 4.3:- Transitivity analysis of sample speeches (Material process).

\begin{tabular}{|c|c|c|}
\hline Actor & Process & Goal \\
\hline I & $\begin{array}{l}\text { said, } \\
\text { receive, congratulate, make, need, } \\
\text { thank }\end{array}$ & call, partner, voice, help \\
\hline We/Pakistanis/ all /our & $\begin{array}{l}\text { Met, request, subjected, heard, } \\
\text { Build, say, made, prepared, agree, } \\
\text { party, opened, usher, want, say, tell, } \\
\text { told, accepts, negotiating, live, have, } \\
\text { invade, buy, pay, remain, going, } \\
\text { reached, develop, make }\end{array}$ & $\begin{array}{l}\text { Bitter truth, tactics, things, } \\
\text { youth, better/greater Pakistan, } \\
\text { like, commitment, anything, } \\
\text { some settlement, relations, new } \\
\text { page/chapter, new era, destroy, } \\
\text { fight, principles, realities, } \\
\text { attack, lasting, permanent } \\
\text { solution, Kashmir, neighbors, } \\
\text { refugees, country, back, } \\
\text { friends, Bengal, territory, } \\
\text { thankful, to lick dust, position, } \\
\text { mistakes, } \\
\text { Solace, be called, } \\
\text { complimentary word, dubious } \\
\text { satisfaction, balance }\end{array}$ \\
\hline
\end{tabular}

4.4 Detection of the Relational Process in sample speeches explaining with few examples

Table 4.4:- Relational Process.

\begin{tabular}{|l|l|}
\hline Attributive & Identifying \\
\hline $\begin{array}{l}\text { Pakistan's position is entirely different because, for us, } \\
\text { the nuclear threat is real and immediate. }\end{array}$ & $\begin{array}{l}\text { Pakistan faces a problem of an extraordinary } \\
\text { magnitude. } \\
\text { A problem of an extraordinary magnitude is faced by } \\
\text { Pakistan. }\end{array}$ \\
\hline $\begin{array}{l}\text { Please do not permit this kind of naked, shameful } \\
\text { barbaric aggression to hold sway. }\end{array}$ & $\begin{array}{l}\text { If we must use complimentary words, the present } \\
\text { exercise can be called a triumph in futility. } \\
\text { The present exercise can be called a triumph in futility } \\
\text { if we must use complimentary words. }\end{array}$ \\
\hline
\end{tabular}

The above table 4.4 presents the Relational Process in the sample speech of Z.A Bhutto with help of examples. Relational process has two participants named attributive and identifying and the researcher explains each participant from examples of selected speech in order to make a better understanding of this type of process.

4.5 Role of Modal Verbs as presented by the Linguist named Zhang Guoling (2006) to signal politeness

Table 4.5:- Modal Verbs (Zhang Guoling, 2006).

\begin{tabular}{|l|l|l|l|}
\hline \multicolumn{2}{|l|}{ Low politeness } & Median politeness & High politeness \\
\hline Positive & $\begin{array}{l}\text { Can, may, could, might, } \\
\text { dare }\end{array}$ & $\begin{array}{l}\text { Will, would, should, } \\
\text { shall }\end{array}$ & $\begin{array}{l}\text { Must, ought to, need, } \\
\text { has/had to }\end{array}$ \\
\hline Negative & $\begin{array}{l}\text { Needn't, doesn't / } \\
\text { didn't, need to, have to } \\
\text { shouldn't, isn't/wasn't }\end{array}$ & $\begin{array}{l}\text { Won't, wouldn't, } \\
\text { can't couldn't, mayn't, } \\
\text { mightn't, hasn't / } \\
\text { hadn't to }\end{array}$ \\
\hline
\end{tabular}

In the above table 4.5 , the researchers present the modal verbs that what kind of modal verbs fall in what kind of politeness as there are three kinds of the politeness including low politeness, median politeness and high politeness. This above table could help in better understanding of the two types of politeness, which is positive politeness and negative politeness. 
4.6 Modality analysis of the sample speeches (Modal verbs)

Table 4.6:- Total raw and percentage score of politeness strategies used by the speaker.

\begin{tabular}{|c|c|c|c|c|c|c|c|c|}
\hline \multirow{2}{*}{$\begin{array}{l}\text { Sample } \\
\text { Speech }\end{array}$} & \multirow{2}{*}{$\begin{array}{l}\text { Total } \\
\text { Number }\end{array}$} & \multirow[t]{2}{*}{ Politeness } & \multicolumn{2}{|c|}{ Low politeness } & \multicolumn{2}{|c|}{ Median politeness } & \multicolumn{2}{|c|}{ High politeness } \\
\hline & & & No & $\%$ & No & $\%$ & No & $\%$ \\
\hline 1. & 4,954 & Positive & 32 & $0.65 \%$ & 82 & $1.66 \%$ & 18 & $0.37 \%$ \\
\hline & & Negative & 14 & $0.29 \%$ & 12 & $0.25 \%$ & 3 & $0.07 \%$ \\
\hline
\end{tabular}

In table 4.6, the researchers have presented a statistical analysis of both selected speech of Z.A Bhutto in order to show different kinds of politeness used in the speech. In sample speech 1, total numbers of words are 4,954 where in the column of low politeness, the percentage of positive politeness is $0.65 \%$ and negative politeness is $0.29 \%$. The very next column named median politeness of sample speech 1 has percentile $1.66 \%$ of the positive politeness while negative politeness is $0.25 \%$. In the last column of high politeness, positive politeness is $0.37 \%$ and negative politeness is $0.07 \%$.

4.7 Personal Pronouns in the sample speech

Table 4.7:- Total no. of Personal Pronoun used in the sample speech.

\begin{tabular}{|c|c|c|}
\hline \multirow{2}{*}{\multicolumn{2}{|c|}{ Personal Pronoun }} & \multirow{2}{*}{$\begin{array}{l}\text { Sample Speech } 1 \\
\text { My country beckons me }\end{array}$} \\
\hline & & \\
\hline \multirow[t]{2}{*}{ First Person } & $\mathrm{I}(\mathrm{me})$ & 90 \\
\hline & We(us) & 80 \\
\hline Second Person & You(you) & 57 \\
\hline \multirow[t]{4}{*}{ Third Person } & He(him) & 16 \\
\hline & She(her) & 0 \\
\hline & It(it) & 53 \\
\hline & They(them) & 41 \\
\hline \multicolumn{2}{|c|}{ Possessive pronoun } & \\
\hline \multicolumn{2}{|l|}{ My (mine) } & 28 \\
\hline \multicolumn{2}{|l|}{ Our(ours) } & 9 \\
\hline \multicolumn{2}{|l|}{ Your(yours) } & 6 \\
\hline \multicolumn{2}{|l|}{ His (his) } & 5 \\
\hline \multicolumn{2}{|l|}{ Her(hers) } & 0 \\
\hline \multicolumn{2}{|l|}{ Its (its) } & 14 \\
\hline \multicolumn{2}{|l|}{ Their (theirs) } & 17 \\
\hline
\end{tabular}

This table 4.7 presents total number of personal pronouns used in the sample speech of Z.A Bhutto.

\section{Discussion:-}

From table 4.1, we can have a general view of the speech. We can see the total words of sample speech 1are 4,594, including 313 sentences. The average length of words is 4.610 and sentence mean length is 14.678. The analysis shows that Bhutto chose to explain the complicated situation by short sentences, which add energy to any speech (Corbett 465). He also used short sentences to frame analogy and provide varied historical references as he perceived that other countries viewed the dismemberment as a war of liberation. His greatest challenge in communicating with a disparate was vast audience. Bhutto used short sentences to simplify the message, and his balanced and varied diction used both formal language and colloquialism to reach his vast, multilingual and global audience. Yet his formal, highly stylized language is also laced with diplomatic jargon quite expected in the Council. Speakers from former colonies have to focus strongly on their diction or risk coming across as deficient, semi-literate or pedantic but Bhutto with his Oxford education faced no such challenge. And having been in the UN since 1957, he knew the demands of the register, genre and the importance of tone (Junejo 33).

\section{Transitivity Analysis (Ideational Function):-}

The ideational function is represented in text by transitivity. It is a basic semantic system, which construes the world of experience into a manageable set of process types. Halliday divides these processes into six types: material process, mental process, relational process, behavioral process, verbal process and existential process. 


\section{Material Process:-}

Material process is a process of "doing". The process is usually indicated by a verb expressing an action, either concrete or abstract. There are usually two participants in the process: Actor and Goal. Actor is comparable to the Subject and Goal is comparable to the Object and both of them are usually realized by noun phrases. When the participants both exist, the clause can be either in active voice or in passive voice.

From the above table (see Table 4.3), we can see the Actors of the sample speech is I and we /Pakistanis/ all. Material process, as a process of doing, is a good choice in the address to demonstrate the situation of Pakistan in the different spheres of life. And it can also arouse the confidence of Pakistani people and Security Council towards him and Pakistan.

Bhutto excessively made use of first- person, singular pronoun and he referred to himself about 88 times in the statement: he "spoke from the heart", spoke about his son, his reputation as speaker and his victory in the polls, which was "greater than Mujib-ur-Rehman's" (Abbas, S 2011). It is difficult to separate the political from the personal in some paragraphs.

\section{For Example;}

- Finally, I (Actor)am (Material Process) not a rat (Goal). I (Actor) have never ratted (Material Process) in my life (Goal). I (Actor) have faced (Material Process) assassination attempts (Goal), I (Actor) have faced (Material Process) imprisonments (Goal). I (Actor) have always confronted (Material Process) crises (Goal). Today $\boldsymbol{I}$ (Actor) am not ratting (Material Process), but $\boldsymbol{I}$ (Actor) am leaving (Material Process) your Security Council (Goal). I (Actor)find (Material Process) it disgraceful to my person (Goal) and to my country (Goal) to remain here a moment longer than is necessary. I (Actor) am not boycotting... (Material Process). (see speech 1: 47-48)

Seeing Bhutto's tremendous eruditeness, these statements were a deliberate choice and really tested the limits of diplomatic discourse and truth. Why did he do it? Though it makes for egoistic prose it achieved an important rhetorical goal; the focus of the statement shifted from Pakistan to Bhutto. The man was more visible than his country.

Bhutto also made use of 'we' in order to show that he is talking about on behalf of Pakistani nation and he also showed that Pakistan has the same views regarding any particular issue as he has in his mind.

For Example;

- We (Actor) have been subjected (Material Process) to dilatory tactics (Goal). (Speech 1:11)

- We (Actor) will build (Material Process) a greater Pakistan (Goal). (Speech 1:64)

- We (Actor) will fight (Material Process); we (Actor) will go (Material Process) back and fight (Goal). My country (Actor) beckons (Material Process) me (Goal). Why should I (Actor) waste (Material Process) my time here in the Security Council (Goal)? I (Actor) will not be a party (Material Process) to the ignominious surrender of a part of my country (Goal). You (Actor) can take (Material Process) your Security Council (Goal). Here you (Actor) are (Material Process). I (Actor) am going (Material Process). (Speech 1: 306-313)

In the video footage of speech in Security Council, he ended the statement, tore up his papers and walked out the hall with the Pakistani delegation in tow. These symbolic gestures showed his utter disregard dissatisfaction with the proceedings. Even on paper Bhutto's rudeness is significant. He called the Russian representative "a Tsar" (Speech $1: 45)$ and compared the Indian foreign minister to "a janitor":

- Mr. President, you referred to the "distinguished" Foreign Minister of India. If he can be Foreign Minister of India, $\boldsymbol{I}$ (Actor) could have been Prime Minister of united India. But $\boldsymbol{I}$ (Actor) would (Material Process) rather be a janitor in a free country (Goal). (Speech 1:41)

Pronominal references also have been used creatively in the statement. The use of second person pronoun "you" made it seem that Bhutto was addressing the listener directly. This gave the entire statement the impact of face-toface conversation - inclusive and personable - despite being delivered to a larger audience:

- $\quad$ You (Actor) do not need (Material Process) a Secretary General (Goal). You (Actor) need (Material Process) a chief executioner (Goal). (Speech 1:40)

- But the Indians are so short-sighted... But you(Actor) know they do not have (Material Process) vision (Goal). (Speech 1:41) 


\section{Mental Process:-}

Mental process is a process of feeling, thinking and seeing. Actor is not the real subject of doing, but the feeling. It represents inner experience, such as "perception", "reaction" and "cognition".We call the two participants are Sensor and phenomenon.

For Example;

- The great powers will forgive (Mental Process) me (Sensor). I (Sensor) have addressed them in this moment of anguish (Mental Process), and they should understand (Mental Process). (Speech 1:164-165)

- I (Sensor)know (Mental Process)the United Nations; I (Sensor)know (Mental Process)the Security Council I have attended their sessions before.(Speech 1:2)

From all above examples, we can see that mental process, as a process of sensing, appeals to the audience's inner heart to connect the political beliefs, ambitions with their expectation, hope in a clear and emphasized way. In this way, the audience's emotion of promotion and willingness to devotion is aroused and strengthened. Bhutto realized that Pakistanis would be listening and tried to address them while talking to the Council. In essence, Bhutto spoke to "two" audiences simultaneously and varied his discourse accordingly.

- The Pakistani nation is a brave nation. One of the greatest British generals said that the best infantry fighters in the world are the Pakistanis. (Speech1: 108-109)

- If India talks about the will of the people of East Pakistan and claims that it had to attack Pakistan in order to impose the will of the people of East Pakistan, then what has it done about Kashmir? East Pakistan is an integral part of Pakistan. Kashmir is a disputed territory. Why does India then not permit it to exercise its will? (Speech1: 136-139)

The above sentences are examples of showing the fact that Pakistan is an independent and sovereign state and Kashmir is a disputed territory. After India's nuclear test on May 1974, Bhutto sensed a great danger for Pakistan. So Nuclear program was planned to start for the safety measures of Pakistani state. The speaker tried to define Pakistan and the rights of Pakistani people. And he also tried to define wishes and requirements of Muslims living both in Pakistan and Muslim. These Muslims meant to be elements of a single entity. Bhutto has been associated with the nuclear program from 1958 as minister to 1979 when he was sent to the gallows (Babar,F).

- My countrymen, my people, are dying. So I think I can facilitate your efforts if I speak now. Perhaps this will be my last speech in the Security Council. (Speech 1:19-21)

In above lines, he seems to fail miserably and shamefully, farce, fraud and draping ugly realities are the words used for Security Council. Bhutto's disgust for the Security Council is pretty much evident from the words. He is referring to the East Pakistanis as "my countrymen", "my people" that means he owns them. He mentioned a phone call from his son asking to go back with a document of abject surrender that reflected his firmness for not accepting the document of surrender and his family's involvement and seriousness about the issue. Bhutto seems somewhat desperate when he says, "perhaps this will be my last speech in security council".

- I am not boycotting. Impose any decision, have a treaty worse than the Treaty of Versailles, legalize aggression, legalize occupation, legalize everything that has been illegal up to 15 December 1971... My country beckons me. (Speech 1:303-307)

The above single example reveals that the government hopes the Pakistani can join together and rebuild their confidence and believes to defeat all worst thought and preparations of the worst enemies. And here we can see that he trusted his nation that they would support him and his decisions. So he permitted Security Council to come what may. Apart from that, this statement also broke several conventions of diplomatic discourse as it was simultaneously rude, belligerent and extremely personal. Bhutto's language was belligerent on occasion and his tone and body language were accusatory throughout. He used elaborate hand gestures when talking of "legalization of aggression" (Speech 1:39).

\section{Relational Process:-}

Relational process is a process of being. It can be divided into two modes: attributive relation and identifying relation. The first means what properties an object possesses or what category it can be put into. And the other means that an entity is uniform. It is used widely in describing people and objects (see Table 5).

- Pakistan faces a problem of an extraordinary magnitude (Identifying). (Speech 1)

A problem of an extraordinary magnitude is faced by Pakistan. 
Relational process, as a process of being, is appropriate to explain the complex relationships between some abstract items because it sounds definite. As a result, the process accounts for a large proportion in these addresses to elaborate the relationship between traditional ideals and their beliefs. Such an elaboration can reach the Z.A Bhutto's aim of making the reasoning naturally and unconsciously accepted and making the required sacrifice in the speech willingly taken by the audience (Cheng Yumin, 2007).

\section{Modality Analysis (Interpersonal Function):-}

Modality refers to a speaker's attitudes towards or opinion about the truth of a proposition expressed by a sentence. It also extends to their attitude towards the situation or event described by a sentence.

\section{Modal Verbs:-}

The statement in $U N O$ uses several imperative sentences, which convey a power differential by giving orders or commands. The modal verbs (must, will, can etc) are often used and implies that the speaker is somehow in the position to give such commands; this was an extraordinary choice given the rhetorical conditions. According to the statistics, it is obvious that modal verbs are used to convey the addresser's attitudes and judgment, with an average of $0.8 \%$ in the whole speeches. The high percentage of the use of modal verbs is appropriate to the speaking since the addresses are delivered in spoken form. Compared with other verbs, modal verbs are more easily identified and understood and then accepted because at the time of listening to the speeches, there is no time for the audience to reflect. As the table 4.6 represents that in sample speech 1, the use of Low Positive Politeness is $0.65 \%$ and Low Negative Politeness is $0.29 \%$ of the whole speech.

\section{For Example;}

- Do not come back with a document of surrender. (Speech 1:40)

As we can see in the very above example that declarative sentences make statements and give information about some noun or verb. Bhutto created an image of power despite with strong verbs such as "do not" and "cannot do". In sample speech 1, Median Positive Politeness is $1.66 \%$ and Median Negative Politeness is $0.25 \%$ used in the whole speech while in sample speech 2, Median Positive Politeness is $1.44 \%$ and Median Negative Politeness is $0.45 \%$ of the whole political speech.

\section{For Example;}

- We will build a new Pakistan. We will build a better Pakistan. We willbuild a greater Pakistan. (Speech 1:62-64)

- Leningrad was besieged for a thousand days. People who want to be free and who want to maintain their personality will fight and will continue to fight for principles. (Speech 1:114-115)

It was very much clear to Bhutto that Dacca is going to fall and he was mentally prepared for it. But he was off the thought that is going under occupation of a foreign country. That is why all the examples he gave of occupation to rebuilding of the nations. He made it clear to Security Council and Pakistanis that he and Pakistanis are not disappointed of the situation. Pakistan will be rebuilt.

High Positive Politeness used in sample speech 1 is $0.37 \%$ and High Positive Politeness is $0.07 \%$.

For Example;

- I have some home truths to tell the Security Council. The world mustknow. My people mustknow. (Speech $1: 40)$

\section{Tense:-}

Tense is the time of a clause. Halliday (1994) points out that primary tense means past, present or future at the moment of speaking; it is the time relative to "now".

Sample speech represents that simple future tense is primarily used to show the planned or expected things in the future. The tense helps the Z.A Bhutto to lay out his or his government's following reforms or steps taken in his term to foster the buildup of the country and the corresponding change or results of these measures in the future. In this way, the government's objectives are shown and at the same time, the audience's confidence is built by the prospect of the beauty and prosperity of the future life. It will be a natural result that the Pakistani people will follow the government's direction and guidance in the next years and thus the addresses goal of seeking support is achieved. Simple past and present perfect tenses are used to refer to the actions or things in the past. Their function lies in that the political personalities usually state the achievements in the founding of the country or in the last term 
or recall the positive or negative experiences in the past as basis or incentive of his following actions. By this means, his respect for the past is displayed and it can also make his plans reasoning and fully grounded (Cheng Yumin, 2007).

\section{Personal Pronouns:-}

From table 4.7, we can find out that the first person is used most. For example, the use of the first person pronoun "we" is to shorten the distance between the speaker and the audience, regardless of their disparity in age, social status and professions etc. The use of 'I' and 'my people' is excessive that shows that he was very confident about his personal abilities and people of Pakistan's support. Moreover he speaks as if personified Pakistan is speaking; people of Pakistan trust him and he trusts people of Pakistan. He is pretty straightforward when he says, "But I must say, whether the members like it or not, that the Security Council has denied my country that justice." Putting all the formalities and supposed softness, he speaks for his people and his country with firm stance and dedication. It is evident that he really owns Pakistan and Pakistani people. It may include both the speaker and the listener into the same arena, and thus make the audience feel close to the speaker and his points.

\section{Textual Analysis:-}

The textual function refers to the fact that language has mechanisms to make any stretch of spoken or written discourse into a coherent and unified text and make a living passage different from a random list of sentences. Here, we take Sample 1 as an example.

Though there are several stylistic features used in the statement where the researcher will focus on those that are intimately connected to audience, purpose and message. Bhutto used emotional nuance through rhetorical question and irony, fulfilled purpose through metaphors and metonymy, and stressed the message through anaphora and apostrophe.

There is a charge on Z.A Bhutto that he tore up a Polish resolution in the Security Council that, if accepted, would have saved Pakistan in 1971. Here is a fact according to Khalid Hasan which he mentioned in his article named 'Did Bhutto break up Pakistan?' that, "What Bhutto tore up was not this resolution but his notes and doodles." (para, 5). It was just aggression of Bhutto that Security Council was not showing worthy attitude towards Pakistan and its people. Benazir Bhutto often called her father as an intellectual giant, a thinker, author and orator. His courage was such that he preferred to face death for his beliefs and embraced martyrdom.

There is a discernable pattern of rhetorical questions followed by historical reference. The rhetorical question is used to invoke audience participation and make them feel that the speaker shares their values. It was Bhutto's signature style in campaign speeches, where he used it to assume a defiant posture. Here he used it to create doubts in the listener's mind regarding India.

For Example;

- What hope will India give to the people of East Pakistan? What picture of hope is it going to give when its own people in Western Bengal sleep in the streets, where there is terrible poverty, where there is terrible injustice and exploitation, when the parliamentary rule in West Bengal has been superseded by presidential rule? (Speech 1: 46)

\section{Rhetorical Questions:-}

Rhetorical questions induce the listeners to make an appropriate response and are good devices to keep the audience rhetorically engaged. Here Bhutto used contrasting elements: hope and injustice, presidential rule and parliamentary rule to augment his broader argument of justice and injustice.

Apart from that, Bhutto used apposition exquisitely as irony (emotional nuance) in the statement.

For Example;

- If he can be Foreign Minister of India, I could have been Prime Minister of united India. But I would rather be a janitor in a free country. (Speech 1: 41)

- I don't see what objection he has to it if he sees some similarity between his [Russian] empire and the Roman Empire. (Speech 1: 42) 


\section{Ironical References:-}

These Ironical references are rude, sarcastic and an extreme example of emotional nuance that flout all rules of diplomatic discourse. Irony shows Bhutto's true understanding of elite press (audience) who are more likely to remember and report hyperbolic phrases rather than any clichés. The ironical references also depict contrasting elements or analogies through rhetorical wordplay: "Foreign Minister", "Prime Minister". It is beyond the scope of this thesis to analyze why Bhutto said this, but one reason may be that Bhutto decided to live up to his reputation as a fiery speaker by indulging in hyperbole and emotional nuance. In some ways he spoke to these individuals as he spoke to political opponents (Abbas, S. 2011).

\section{Metaphors and Metonymy:-}

He also fulfilled purpose through Metaphors and Metonymy. Metaphors are analogies or comparisons between two similar objects and ideas and express value judgment. Metaphors fulfill the audience's need for simplification. (Corbett and Connors 479) Bhutto's metaphors include:

- My heart is bleeding. (Speech 1:45)

- We are your guinea pigs. (Speech 1: 46)

- Finally I am not a rat. (Speech 1: 47)

They seem like survival metaphors as both guinea pigs and rats are hunted down or used in experimentation. Bhutto used metonymy for brevity. Metonymy substitutes some attribute or suggestive word for what is actually meant and it is useful for rhetorical wordplay. He summed up the past, present and the future of Indo-Pak relations in a word: Carthage (Speech 1:42), an allusion with a powerful, brief affect that may have affected the audience because of his well-known hawkish agenda. The connotations of Carthage are infinite, continuous wars until the complete destruction of the enemy.

\section{Epistrophe:-}

Bhutto stressed his messages through Epistrophe and Anaphora. These stylistic devices are useful for repetition. Epistrophe is the repetition of the same word or phrases at the end of each successive clause or sentence. Bhutto's epistrophe used in the speeches include:

- China was under foreign occupation for years. Other countries have been under foreign occupation. France was under foreignoccupation. Western Europe was under foreign occupation. (Speech 1: 41)

- But you know they do not have vision. The partition of India in 1947 took place because they did not have vision. Now also they are lacking vision. They talk about their ancient civilization and the mystique of India and all that. But they do not have vision at all. (Speech 1: 41)

Epistrophe is effective and resonant as a memory aid because it repeats terms and allows listeners to remember some of the speech. Had Bhutto said, "France, China and Western Europe were under foreign occupation" it would have been effective but dull. Epistrophe enlivens prose and makes it memorable.

\section{Anaphora:-}

Anaphora is the repetition of the same word or phrases at the beginning of each successive clause or sentence. Repetition of by-words is necessary for stress and to provoke a sense of urgency in deliberative discourse. Here are some examples of anaphora from two political speeches of Bhutto:

- Let us build a monument to the veto, a big monument to the veto. Let us build a monument to the impotence and incapacity of the Security Council and the General Assembly. (Speech 1: 41)

- You have to be either on the side of justice or on the side of injustice; you are either on the side of the aggressor or of the victim. There is no third road. It is a black and white situation in these matters; there is no grey involved. You are either for right or you are for wrong; you are either for justice or for injustice... (Speech $1: 47)$

Anaphora gives a ringing tone to any paragraph and in the first example it accompanies a hortative sentence type, "Let us..." which gives it a sanctimonious, bitter aspect. Again Bhutto is reminding the Council of its duties. These devices are used for emphasis and rhythm as they are repetitive and resonate longer in memory. These also show the arrangement of words in increasing importance and add a sense of climax. Bhutto used the terms "right/ wrong" and then followed it with stronger terms "justice/injustice", which are much more appealing terms for a global community. Rhythm piques listeners' expectations and is used to embellish oral and written texts. This attention to 
sentence arrangement brings desired ideas into focus and also shows the arrangement of words in increasing importance. However both stylistic devices working together in one sentence may not have the desired effect (Abbas,S. 2011).

- So what if the whole of East Pakistan falls? So what if the whole of West Pakistan falls? So what if our state is obliterated? We willbuild a new Pakistan. We will build a better Pakistan. We willbuild a greater Pakistan. (Speech 1:59-64)

The whole text is coherent, organized, accurate and logical. So it can help to persuade the public to accept and support his policies and ideas.

\section{Religious and Local Content:-}

Meanwhile, we can also find Religious Content in his speech in order to strengthen his point of view and look at the following examples:

- ...but later on he corrected himself to say that the population of Bengal—of Muslim Bengal—was 76 million. (Speech 1:15)

- Muslim Bengal was a part of Pakistan of its free will, not through money. (Speech 1:248)

And apart from that, Bhutto was more successful with his indirect audience, the Pakistanis. Though theatrical, deeply personal and hyperbolic, the statement served their emotional needs. He told them what they wanted to hear, which was that Pakistan would survive. They wanted to blame someone; India, Russia or an international conspiracy for the near death experience. His statement told the world that Pakistan possessed organic, popular, and forceful leadership that was as anomalous as the nation. The Pakistani press played up the theatrical, florid side of the statement and Bhutto came to power in a burst of popularity.

In any case, all these memories have to be preserved because they constitute the raw material of a history we have not properly recorded or understood. Let me conclude with a quotation from Milan Kundera argued that:

"Man’s struggle against power is memory's struggle against forgetting".(Salahhudin,G. 2004)

\section{Conclusion:-}

On the basis of the above discussion, the researchers can summarize the features of Z.A Bhutto's sample speech as follow. Firstly, he used simple and difficult words both. And in the same way, he made use of short and long and difficult sentences both. His language is somewhat difficult, tricky, ceremonial and colloquial too. Thus, it can convey the important details to a well-recognized community. The purpose of the difficult language is that the targeted audience is literate and modern and he is speaking at an international forum where representatives of all countries are present.

Secondly, from transitivity analysis, we can see material process, a process of doing which has been used most in his speeches. From this process, Z.A Bhutto showed us what the Pakistan has achieved, what they are doing and what strategies they will use in future. And also we can see that with applying transitivity, his speech is trying to arouse the world's optimism towards him and his country. And he made clear his point of view that is based on reality. Because he knew that he was presenting his speech on national and international level, so he presented everything very clear based on reality and without any obscurity in his statements. He used direct words to target his aim.

Thirdly, modality refers to a speaker's attitudes towards or opinion about the truth of a proposition expressed by a sentence. Through the analysis of modality, we can find that Z.A Bhutto made his audience more easily to understand and accept his political speech by means of modal verbs, tense and first person pronouns. He used simple present tense more in order to present the domestic and worldwide situations ranging from political, economic and cultural fields at present. And then depending on simple future tense, he laid out his following reforms and steps taken in his term. In this way, the government's objectives are shown and at the same time, the audience's confidence is built. Moreover, by using first person pronouns and religious belief, he successfully shortened the distance between him and the audience. So it can help him, persuade the public to accept and support his policies and views.

Bhutto projected himself as a human microcosm of the country. At that moment in the Security Council, he wasPakistan with all its rage, prejudices and complexities. No Pakistani leader would have dared used such rhetoric 
against the superpowers on their own turf. It is also doubtful that any other discourse would have satisfied the Pakistani people in their darkest hour.

\section{References:-}

1. Babar, F. Retrieved from http://www.bhutto.org/article8.php

2. Chapman, S., \& Routledge, C. (2009). "Key Ideas in Linguistics and the Philosophy of Language". Edinburgh. Edinburgh University Press, pp. 225-232.

3. Cheng, Y. (2007). An Analysis of Style Features of Inaugural Speeches Given by American Presidents Based on the Functional Theory of Han Lide. From the thesis of a master. Tai Yuan Science University.

4. Chilton, P., \&Schäffner, C. (1997). Discourse and politics in T.A. van Dijk (ed.) Discourse Studies: A Multidisciplinary Introduction (Vol.2). Discourse as Social Interaction (pp.206-30). London: Sage.

5. Conger, J. (1998). Qualitative Research as the cornerstone methodology for understanding leadership. Leadership Quarterly, 9 (1): 107-121

6. Corbett, Edward P.J \& Robert.J. Connors. Classical Rhetoric for the Modern Student. 4th Ed. New York: Oxford UP 1999.125, 271.

7. Dellinger, B. (1995) Critical Discourse Analysis. Retrievedon 15 April 2016. Retrieved fromhttp://users.utu.fi/bredelli/cda.html

8. Fairclough, N. (1989). Language and Power. London: Longman.

9. Fairclough, N. L. and Wodak, R. (1997). Critical discourse analysis. In T. A. van Dijk (ed.), Discourse Studies. A Multidisciplinary Introduction, Vol. 2. Discourse as Social Interaction (pp. 258-84). London: Sage.

10. Halliday, M.A.K. (1985). Spoken and written language. Oxford: Oxford University Press. Retrieved on $8^{\text {th }}$ April $2016 . \quad$ Retrieved from: http://minerva.ling.mq.edu.au/resource/VirtuallLibrary/Bibliography/sysbibliography.htm

11. Halliday, M.A.K (1994). Halliday and Systemic-Functional Linguistics, Retrievedon 10 April 2016. Retrievedon $7^{\text {th }}$ April 2016. Retrieved from http://language.la.psu.edu/spcom497b/halliday.html

12. Hu Zhuanglin (1988). A Course of Linguistics. Peking: Peking University Press.

13. Junejo, C.A. "Zulfikar Ali Bhutto a Memoir". Trans. Hafizur Rahman. 1996. www.bhutto.org. Ed. Sani Panhwar.Retrievedon $8^{\text {th }}$ April 2016. Retrieved from www.bhutto.org.

14. Matthiessen, C., \& Halliday, M.A.K. (1997). Retrieved from http://minerva.ling.mq.edu.au/resource/VirtuallLibrary/Publications/sfg_firststep/SFG\%20intro\%20New.html

15. Salahuddin, G. (2004, April 04). The News: "A Voyage Round Bhutto". Retrieved from http://bhutto.org/article4.php

16. Sinar, T.S. 2007. Phasal and Experiential Realization in Lecture Discourse A Systemic-Functional Analyis. Medan: Kopertis Wilayah I Sumut-NAD

17. Titscher, S.; Meyer, M.; Wodak, R.; \& Vetter, E. (2000) Methods of text and discourse analysis. London: Sage.

18. Van Dijk, T. A. (2006) 'Politics, ideology, and discourse', in Brown, K. (Ed), The Encyclopedia of language and linguistics. Vol. 9 Oxford; New York:Pergamon Press, pp. 728-740.

19. Van Dijk, T.A. (1994). Discourse analysis and social analysis. Discourse \& Society 5, 163-4. Retrieved from, http://www.discourses.org/OldArticles/Critical\%20discourse\%20analysis.pdf

20. Wang, J. (2010). A critical discourse analysis of BarakObama's speeches. Journal of Language Teaching and Research, Vol. 1, No. 3. (ISSN 1798-4769), pp. 254-261

21. Wilcock. G. (2001). Retrieved from http://www.ling.helsinki.fi/kit/2004s/ctl310gen/GW-MScThesis/node16.html

22. Wodak, R., \&Meyer,M. (2008). Critical Discourse Analysis: History, Agenda, Theory, and Methodology Retrieved from:

23. http://api.ning.com/files/u*T1K3myLuoebug9OFwpJ6KB4dns*zDf-S-8RgQ7t5iG8hHbxTAepx5FiCSegGl8nhSm1sy5iz4*Pn8PfwMivAEXLTk*7Hm/November202024615_01_Wod ak_Ch_01.pdf

24. Wodak,R. (1989). Language, Power and Ideology. Journal of language and politics (2007). ISSN 1569-2159. Retrieved from: http://www.ling.lancs.ac.uk/staff/wodak/papers/ideology_jlp.pdf 